Eur. J. Clin. Chem. Clin. Biochem.

Vol. 32, 1994, pp. 301-304

(c) 1994 Walter de Gruyter \& Co.

Bcrlin - New York

\title{
Differences Between the Sexes in Cord Blood Clotting Factors
}

By P. van der Salm ${ }^{1}, J . M . H$. Ubachs ${ }^{1}$ and J. W. J. van Wersch ${ }^{2}$

1 Department of Gynaecology

2 Department of Haematology

De Wever Hospital, Heerlen, The Netherlands

(Received July 16/November 5; 1993)

Dedicated to Professor Dr. Dr. Helmut Greiling on the occasion of his 65th birthday

Summary: Sex-related differences are known to exist in the haemostatic variables of adults. In the present study, three clotting factors were measured in cord blood of 191 newborns. A sex-related difference was found for clotting factor VII, with higher plasma levels in female newborns $(p<0.01)$. Factor VIII:c also tended to be higher in female newborns, compared with male newborns $(p=0.07)$. No difference in fibrinogen concentrations was found.

The observed difference between the sexes for clotting factor VII is not easy to understand, but it is in line with studies showing higher concentrations of factor VII in females than in males throughout adult life.

\section{Introduction}

Cardiovascular disease is about twice as frequent in men than in women (1). Various studies have focused on hormonal status (2-4), lipid spectrum (5) and iron storage (6), but no conclusive explanation for this difference in incidence has been found.

Since haemostatic variables (fibrinogen, factor VII and to a lesser extent factor VIII:c) are recognized as important independent risk factors for cardiovascular disease, they have been the subject of exteñsive research $(7-10)$. Sex-related difference in these haemostatic variables have been shown in young adults as well as in the eld= erly $(11-13)$.

The aim of the present study was to document fibrinogen, clotting factor VII and factor VIII:c concentrations in cord blood and to determine whether sex-related differences can be demonstrated in the newborn.

\section{Materials and Mẹthods}

\section{Patients}

Clotting factors VII, VIII:c and fibrinogen were measured in venous cord blood from 92 male and 99 female singleton newborns born between February and August 1992, with a gestational age of 37 weeks or more, and a birth weight between the $2.3 \mathrm{rd}$ and $97.7 \mathrm{th}$ percentile for gestational age (14). The haematocrit values ranged from 0.45 to $0.51 \mathrm{l} / \mathrm{l}$. Maternal exclusion criteria were a diastolic blood pressure $\geq 90 \mathrm{mmHg}$, an endocrine disease, a coagulation disorder, or medication known to interfere with the haemostatic system. Gestational age was determined by the last menstrual date and/or ultrasound determinations. Birth weight was recorded.

\section{Methods}

Venous cord blood samples were collected in plastic, citrate-containing tubes immediately after delivery and after clamping of the umbilical cord. The tubes were filled with 9 volumes of freshly drawn blood and 1 volume of trisodium citrate $(0.11 \mathrm{~mol} / \mathrm{l})$. Citrated plasma was prepared by direct centrifugation for 20 minutes at $1800 \mathrm{~g}$, snap frozen, then stored at $-70^{\circ} \mathrm{C}$. It was thawed with tap water at $37^{\circ} \mathrm{C}$ for 5 minutes before use.

Fibrinogen was determined with the clotting assay of Clauss, a turbidimetric method employing the CTS-fibrinogen reagent on the Chromotime System (Behring, Marburg, Germany). To quantify factor VII we used the chromogenic substrate COA-set of Kabi Vitrum Diagnostica (Mölndal, Sweden). The intra-assay coefficient of variation was $6.9 \%$ at the level of $54.9 \%$. Factor VIII:c was measured with an APTT one stage clotting assay using a deficient plasma (Behring, Marburg, Germany).

\section{Statistics}

The Mann-Whitney $U$ test was used to test the significance of differences between groups at the $\mathrm{p}<0.05$ level. 
Tab. 1 Comparison of the median and interquartile ranges in malc and female neonates.

\begin{tabular}{|c|c|c|c|}
\hline \multirow[t]{2}{*}{ Quantitics } & \multicolumn{2}{|c|}{ Median (interquartile range) } & \multirow{2}{*}{$\begin{array}{l}\text { Signifi- } \\
\text { cance } \\
p\end{array}$} \\
\hline & $\begin{array}{l}\text { Male } \\
\text { nconates } \\
(n=92)\end{array}$ & $\begin{array}{l}\text { Female } \\
\text { neonates } \\
(n=99)\end{array}$ & \\
\hline $\begin{array}{l}\text { Gestational age } \\
\text { (days) }\end{array}$ & $\begin{array}{l}279 \\
(274-285)\end{array}$ & $\begin{array}{l}281 \\
(274-286)\end{array}$ & 0.64 \\
\hline $\begin{array}{l}\text { Birth weight } \\
\text { (g) }\end{array}$ & $\begin{array}{l}3525 \\
(3200-3820)\end{array}$ & $\begin{array}{l}3350 \\
(3070-3750)\end{array}$ & 0.02 \\
\hline $\begin{array}{l}\text { Fibrinogen } \\
(\mathrm{g} / \mathrm{l})\end{array}$ & $\begin{array}{l}2.2 \\
(1.9-2.7)\end{array}$ & $\begin{array}{l}2.2 \\
(1.9-2.5)\end{array}$ & 0.68 \\
\hline $\begin{array}{l}\text { Factor VII } \\
(\%)\end{array}$ & $\begin{array}{l}44 \\
(30-56)\end{array}$ & $\begin{array}{l}50 \\
(36-69)\end{array}$ & 0.004 \\
\hline $\begin{array}{l}\text { Factor VIII:c } \\
(\%)\end{array}$ & $\begin{array}{l}107 \\
(61-166)\end{array}$ & $\begin{array}{l}142 \\
(72-192)\end{array}$ & 0.07 \\
\hline
\end{tabular}

\section{Results}

Results for the levels of fibrinogen, clotting factor VII and factor VIII:c in the cord blood of 92 male and 99 female neonates are summarized in table 1.

Gestational age did not differ between the two sexes.

Birth weight was significantly higher in male neonates than in female neonates. The median fibrinogen concentrations were equal for male and female newborns, although the distribution was Gaussian in males and skewed to the right in females.

Factor VII levels were significantly higher in female than in male newborns (median values $50 \%$ and $44 \%$, respectively, both Gaussian distributed).

Factor VIII:c levels tended to be higher in female than male neonates (median values $142 \%$ and $107 \%$, respectively), but this difference was not significant $(p=0.07)$.

The distribution of the clotting factors for each sex separately is shown in figure la-c.

\section{Discussion}

Studies on gender-dependent differences of plasma fibrinogen concentrations in adults are contradictive. Lee et al. report higher fibrinogen concentrations in women than in men, in the age group of 40-59 years (15). Balleisen et al. also found higher fibrinogen concentrations in females than in males up to 29 years (13), and similar results were reported by Folsom et al. in subjects aged 45-64 years (12). In contrast, Berglund et al. could not demonstrate any influence of gender on fibrinogen con- ${ }^{\circ}$ centration in 24-44 year-old patients (16), and Tarallo
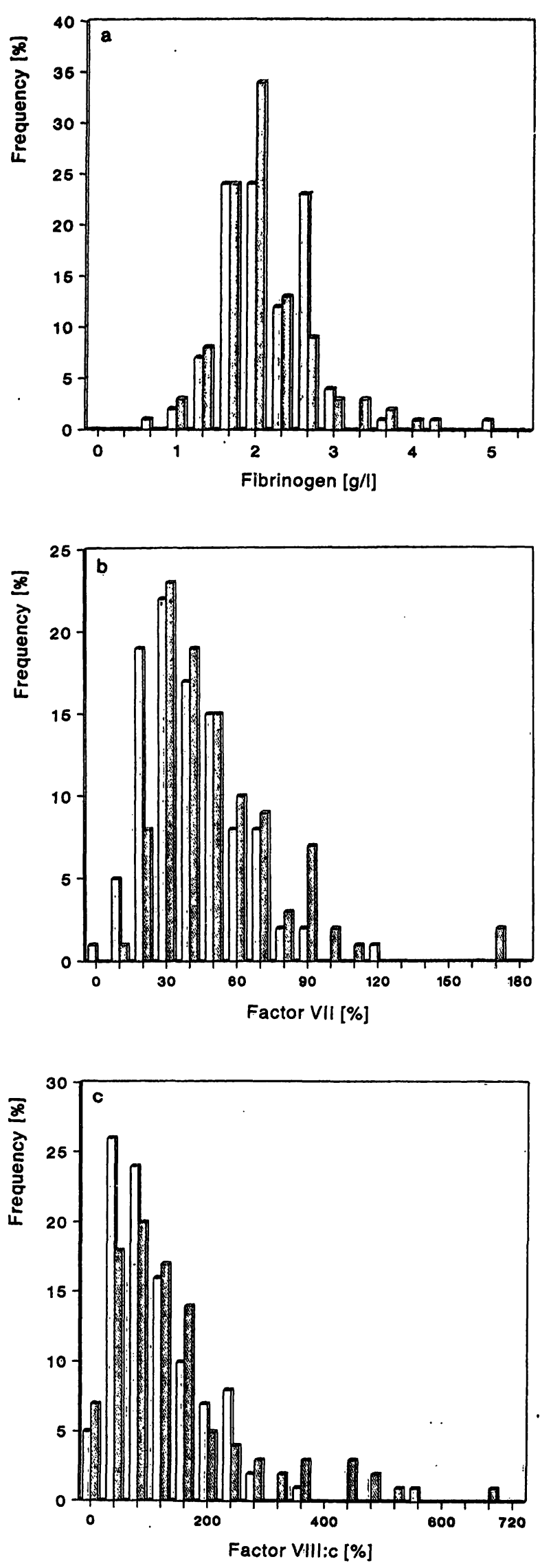

Fig. 1 Distribution of clotting factor concentrations in cord blood.

a) Fibrinogen

b) Amidolytic factor VII

c) Clotting factor VIII:c

Male newborns 
et al. reported no statistical difference between the sexes, except in subjects aged 40-50 years (17). Reports on clotting factor VII are also inconclusive. Balleisen et al. described no gender influence on factor VII levels (13). Folson et al. found higher factor VII levels in women than in men, aged 45-64 years (12), and Kario et al. reported similar results for adults aged 6098 years (11). Less research has been done on sex-related differences in factor VIII:c, but Balleisen et al. reported no difference (13). In the present study in newborns, no difference between the sexes could be demonstrated in plasma fibrinogen concentrations. Factor VII levels in cord blood were significantly higher in female than in male neonates. Higher plasma levels of factor VIII:c in female neonates were found, but the difference did not reach the 0.05 level of significance $(p=0.07)$, possibly because factor VIII:c levels span a wide range.

The clinical relevance of the sex-related differences in factor VII levels in newborns might be questioned, as the plasma levels are lower in males than in females. It is unlikely that this small percentage causes a difference in haemostasis between the two sexes. However, the present study provides information about the distribution of the coagulation risk factors in the sexes at birth. It has been stated that sex-related differences in haemostatic variables are related to hormonal effects.

\section{References}

1. Lerner, D. J. \& Kannel, W. B. (1986) Patterns of coronary heart disease morbidity and mortality in the sexes: A 26-year follow-up of the Framingham population. Am. Heart. J. III, 383-390.

2. Phillips, G. B. (1976) Evidence for hyperoestrogenemia as a risk factor for myocardial infarction in men. Lancet $i i, 14-18$.

3. Heller, R. F. \& Jacobs, H. S. (1978) Coronary heart disease in relation to age, sex, and the menopause. Br. Med. J. 1, 472474.

4. Kolata, G. (1983) New puzzles over estrogen and heart disease. Science 220, 1137-1138.

5. Gordon, T., Castelli, W. P., Hjortland, M. C., Kannel, W. B. \& Dawber, T. R. (1977) High density lipoprotein as a protective factor against coronary heart disease, the Framingham Study. Am. J. Med. 62, 707-714.

6. Sullivan, J. L. (1981) Iron and the sex difference in heart disease risk. Lancet $i, 1293-1294$.

7. Meade, T. W., North, W. R. S., Chakrabarti, R., Stirling, Y., Haines, A. P. \& Thompson, S. G. (1980) Haemostatic function and cardiovascular death: Early results of a prospective study. Lancet $i, 1050-1054$.

8. Meade, T. W., Mellows, S., Brozovic, M., Miller, G. J., Chakrabati, R. R., North, W. R. S., Haines, A. P., Stirling, Y., Imeson, J. D. \& Thompson, S. G. (1986) Haemostatic function and ischaemic heart disease: Principal results of the Northwick Park Heart Study. Lancet $i i ;$ 533-537.
Heller et al. found no association between testosterone and fibrinogen or factor VIII:c, but they found an inverse relationship between testosterone and factor VII in adult males (18). Since male neonates have higher testosterone values than female neonates (19), lower factor VII levels could be expected. The results of the present study are in agreement with this supposition. Moreover, oestrogen replacement therapy after onset of the menopause increases factor VII levels $(12,20)$. This supports the observation that female neonates - experiencing high oestrogen concentrations during the first week of life (19) - have higher factor VII levels. Less is known about hormonal influences on factor VIII:c. A rise in factor VIII:c levels in the postmenopausal period has been reported (13), but not confirmed by others (20).

Although hormonal characteristics may play a role, no definite explanation for the differences found can be given. It is striking, however, that plasma levels of factor VII, an important cardiovascular risk factor, appear to be higher in females than in males from birth to adult life, whereas cardiovascular disease is more frequent in men.

9. Wilhelmsen, L., Svärdsudd, K., Korsan-Bengtsen, K., Larsson, B., Welin, L. \& Tibblin, G. (1984) Fibrinogen as a risk factor for stroke and myocardial infarction. N. Eng. J. Med. 311, 501-505.

10. Ridker, P. M. \& Hennekens, C. H. (1991) Hemostatic risk factors for coronary heart disease. Circulation 83, 1098-1100.

11. Kario, K., Matsuo, T. \& Nakao, K. (1991) Factor VII hyperactivity in the elderly. Thromb. Haemost. 65, 25-27.

12. Folsom, A. R., Wu, K. K., Davis, C. E., Conlan, M. G., Sorlie, P. D. \& Szklo, M. (1991) Population correlates of plasma fibrinogen and factor VII, putative cardiovascular risk factors. Atherosclerosis 91, 191-205.

13. Balleisen, L., Bailey, J., Epping, P. H., Schulte, H. \& van de Loo, J. (1985) Epidemiological study on factor VII, factor VIII and fibrinogen in an industrial population: 1. Baseline data on the relation to age, gender, body-weight, smoking, alcohol, pill-using, and menopause. Thromb. Haemost. 54, 475-479.

14. Kloosterman, G. J. (1970) On intrauterine growth. Int. J. Gynaecol. Obstet. 8, 895,

15. Lee, A. J., Smith, W. C. S., Lowe, G. D. O. \& Tunstall-Pedoe, H. (1990) Plasma fibrinogen and coronary risk factors: The Scottish Health Study. J. Clin. Epidemiol. 43, 913-919.

16. Berglund, U., Wallentin, L. \& von Schenck, H. (1988) Platelet function and plasma fibrinogen and their relations to gender, smoking habits, obesity and beta-blocker treatment in young survivors of myocardial infarction. Thromb. Haemost. 60 , $21-24$. 
17. Tarallo, P., Henny, J., Gueguen, R. \& Siest, G. (1992) Reference limits of plasma fibrinogen. Eur. J. Clin. Chem. Clin. Biochem. 30, 745-751.

18. Heller, R. F., Meade, T. W., Haines, A. P., Stirling, Y., Miller, N. E. \& Lewis, B. (1982) Inter-relationships between factor VII, serum testosterone and plasma lipoproteins. Thromb. Res. $28,423-425$.

19. Weinberg, J., Zimmerberg, B. \& Sonderegger, T. B. (1992) Gender specific effects of perinatal exposure to alcohol and other drugs. In: Perinatal Substance Abuse: Research Findings and Clinical Implications (Sonderegger, T. B., ed.) The John Hopkins University Press, Baltimore, Maryland:

20. Poller, L., Thomson, J. M. \& Coope, J. (1977ั) Conjugated equine oestrogens and blood clotting: $\mathrm{A}$ follow-up report. $\mathrm{Br}$. Med. J. 1, 935-693.

Dr. J. W. J. van Wersch

De Wever Hospital

P. O. Box 4446

NL-6401 CX Heerlen

The Netherlands 